\title{
Solar still for saline water desalination for low-income coastal areas
}

\author{
Asiful Hoque ${ }^{1} \cdot$ Ashif Hasan Abir $^{1} \cdot$ Kironmoy Paul Shourov $^{1}$ \\ Received: 16 September 2018 / Accepted: 15 May 2019 / Published online: 22 May 2019 \\ (c) The Author(s) 2019
}

\begin{abstract}
Solar still is a simple device that utilizes the evaporation-condensation technique to convert impure saline water into the distilled water by eliminating dissolved salts as well as other dissolved impurities and suspended solids. This study aims to produce fresh drinking water from saline water with solar still in the context of Bangladesh. For this study, a pilot-scale solar still with an effective surface area of $0.214 \mathrm{~m}^{2}$ is fabricated with mild steel sheet. At first, solar still productivity is evaluated by varying basin water amount by $3 \mathrm{~L}, 3.5 \mathrm{~L}, 4 \mathrm{~L}$ and $4.5 \mathrm{~L}$ synthetic water. Experimental investigations show a decrease in water production with an increase in basin water amount. The optimum basin water amount is found to be $3.5 \mathrm{~L}$ at which distillate production is maximized. Then, the effect of salt concentration is assessed by synthetic solutions with $2000 \mathrm{ppm}, 5000 \mathrm{ppm}$ and $8000 \mathrm{ppm}$ total dissolved solids (TDS). An inverse relation is found between salt concentration and freshwater production. Lastly, real seawater is fed to the basin and an average freshwater production of $2.38 \mathrm{~L} / \mathrm{m}^{2}$-day is obtained with a removal efficiency of $99.87 \%, 99.83 \%, 99.78 \%$ and $99.81 \%$ for turbidity, chloride, TDS and electrical conductivity respectively.
\end{abstract}

Keywords Saline water $\cdot$ Solar still $\cdot$ Solar desalination $\cdot$ Drinking water

\section{Introduction}

Water is the source of all forms of lives on earth which is equally important to the human as well as entire wildlife. It is estimated that about 3.6 billion people are faced with water crisis at present and by 2050 , the number may increase to 4.8-5.7 billion (UN-Water 2018). In the coastal regions of Bangladesh, about 15 million people are compelled to drink saline water and 30 million people are deprived of drinking water for lack of safe water sources (Hoque 2009). In this context, desalination of water using solar still is a viable option to provide drinking water in remote and arid regions of Bangladesh, especially for smaller communities and domestic use.

Solar still is a device that harvests solar energy to produce fresh drinking water from saline water by utilizing the evaporation-condensation technique. The process is entirely dependent on solar radiation and does not involve any supply of external energy, which makes it an attractive

Asiful Hoque

asiful135@yahoo.com

1 Civil Engineering Department, Chittagong University of Engineering and Technology, Chittagong, Bangladesh choice for the regions that receive abundant solar energy throughout the year. A greater portion of coastal regions of Bangladesh is affected by the salinity of both groundwater and surface water. Many coastal regions around the world, especially in the Middle East and North Africa, are now dependent on treated saline water (Buros 2000). According to the International Desalination Association (IDA), 18,426 desalination plants around the world are in operation at present. The desalination plants use conventional desalination processes, namely reverse osmosis (RO), multi-stage flash (MSF), multi-effect distillation (MED), etc., which are both energy- and cost-intensive, require huge initial investment, skilled workforce, regular maintenance and expertise for smooth operation. Moreover, these plants are not favorable for small-scale water supply for their large capital cost of plant and coverage pipeline. In such cases, where the power supply is not available, water sources are saline and demand is less than $200 \mathrm{~m}^{3} /$ day. Solar still desalination remains the only process that can be utilized for freshwater production (Tiwari et al. 2003).

However, the main drawbacks of solar stills involve the requirement of large installation areas, lower productivity and higher land cost associated with the larger land requirement (Ayoub and Malaeb 2012). So, the studies mainly focus 
on enhancing the water production from solar still to negate the limitations as well as on keeping the unit cost of water as low as possible. According to Abujazar et al. (2016), the productivity of a solar still is influenced by ambient conditions (solar radiation, ambient temperature, wind velocity, etc.), operating conditions (brine water depth, saline concentration, etc.) and design conditions (cover angle, insulation, etc.). The behavior of solar stills with different configurations and different working conditions has been widely studied over the past few decades. Since the distribution of solar radiation around the world is non-uniform, the performance studies of solar still are required to be replicated under the climatic condition of Bangladesh. According to the meteorological data obtained from Bangladesh Meteorological Department (BMD), Bangladesh receives an average $3.125 \mathrm{~kW} \mathrm{~h} / \mathrm{m}^{2}$-day solar radiation during summer (March-June) with sunshine hour of 4.4-7 h while an average $2.31 \mathrm{~kW} \mathrm{~h} / \mathrm{m}^{2}$-day solar radiation during winter (October-March) with 6-9 sunshine hours. Thus, the condition of Bangladesh is in favor of the solar still application for drinking water production. In addition, solar still is easy to construct with local labor force using low-cost readily available materials and even illiterate people can operate solar still due to its very simple operations, which make it an excellent choice in the context of Bangladesh.

This study aims to evaluate the effect of brine water depth and the effect of salt concentration on the productivity of a single slope passive solar still under the climatic condition of Chittagong, Bangladesh. It is an established fact that water production from solar still decreases with an increase in brine water depth (Khalifa and Hamood 2009). The effect of brine depth is studied to select an optimum water depth for the fabricated solar still. With the optimized water depth, the effect of basin water salt concentration on productivity is also studied using synthetic saline water. Later, the solar still is provided with real seawater to compare the productivity obtained from synthetic water. Finally, water parameters are tested to determine the removal efficiencies of dissolved impurities as well as suspended particles and to ensure the quality of distilled water upon comparing with WHO guideline.

\section{Experimental procedure}

\section{Setup specification}

For the experimental studies, a single slope solar still is fabricated with a mild steel sheet of $0.8 \mathrm{~mm}$ thickness. The solar still has an effective area of $0.214 \mathrm{~m}^{2}$ with a basin dimension of $650 \mathrm{~mm} \times 330 \mathrm{~mm}$. The front wall is $100 \mathrm{~mm}$ high and rear wall is $240 \mathrm{~mm}$ high. Transparent glass of $5 \mathrm{~mm}$ thickness is used as cover at an inclination of $23^{\circ}$ with the horizontal, which is nearly equal to the latitude of the experimental site $\left(22.5^{\circ}\right)$, as suggested by Singh and Tiwari (2004), to minimize radiation loss due to reflection. Moreover, this optimized angle ensures to receive solar radiations normal to the glass surface throughout the year (Srivastava and Agrawal 2013). A distillate collection trough is built integrally with the setup by bending of mild steel sheet with an inclination of $20 \mathrm{~mm}$. Three steel nipples of $18.75 \mathrm{~mm}$ diameter are fitted in the rear wall and two side walls to connect PVC hose pipes with the setup for feeding and discharging water. Inner walls of the solar still are painted black to protect the still from corrosive brine as well as to absorb more heat from solar radiation. Since heat plays the vital role in the distillation process of solar still, proper insulation is necessary to avert heat loss from the inside to the environment in order to improve productivity. For the insulation of glass cover, all-purpose silicone sealant is used along the cover edge to prevent vapor escape from the still. Silicone is flexible when applied and can be easily removed when necessary for maintenance purpose. For the insulation of the walls, 30-mm-thick cotton pad is attached on the outer side of the walls. Additionally, 15-mm-thick expanded polystyrene sheet is attached over the cotton pad for further insulation as well as to protect the cotton from degradation. Figure 1 represents a schematic diagram of the designed solar still.

\section{Working procedure}

The experimental investigations are carried out at Chittagong University of Engineering and Technology, Chittagong, Bangladesh $\left(22.46^{\circ} \mathrm{N}, 91.97^{\circ} \mathrm{E}\right)$. Both synthetic saline water and seawater are used for this study. The experiments involved in this study are the investigation of the

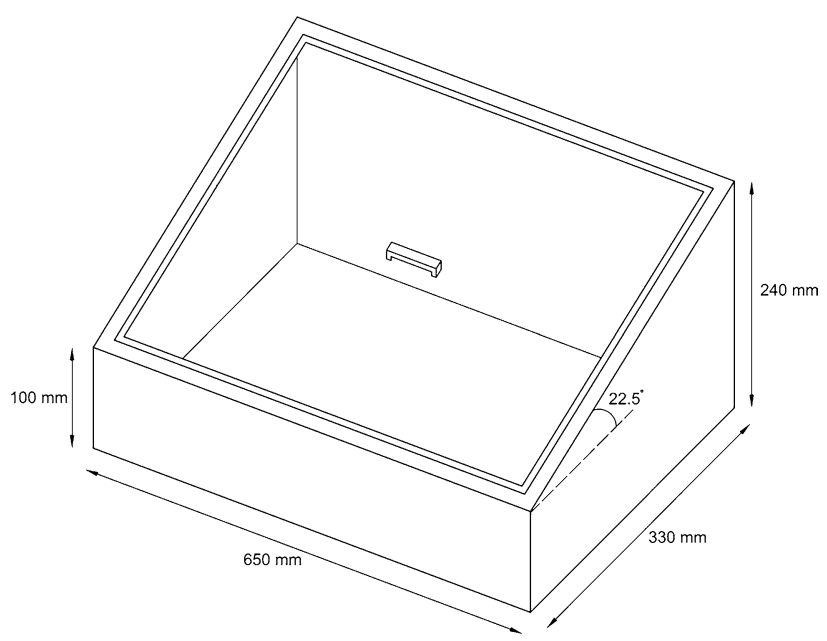

Fig. 1 Schematic diagram of solar still with dimensions 
effect of water amount, effect of salt concentration and solar still performance with seawater.

The experiments are performed on clear sunny days and are triplicated to have a clear understanding of the experimental findings. Before the commencement of the experiments, inside of the basin is washed by water flushing. The experiments are conducted for $8 \mathrm{~h}$ of direct operation under solar radiation from 9 a.m. to 5 p.m., and then $16 \mathrm{~h}$ of indirect operation from 5 p.m. to 9 a.m. of the following day. During $8 \mathrm{~h}$ of direct operation, ambient temperature, glass cover temperature, basin water temperature, relative humidity and distillate production are recorded in each hour. During $16 \mathrm{~h}$ of overnight operation, only accumulated distillate is recorded before 9 a.m. of the following day. The ambient temperature, basin water temperature and relative humidity are recorded with a digital thermometer, whereas glass cover temperature is recorded with a laser thermometer. The distillate is measured using a measuring cylinder with a resolution of $1 \mathrm{~mL}$. The glass cover is oriented toward south-east direction up to 12 p.m., and then orientation is changed toward south-west direction. The distillate is collected in a PET bottle during each experiment.

\section{Effect of basin water depth}

Amount of basin water is the most important parameter that affects the solar still productivity. Since the operation of solar still is entirely dependent on solar radiation and no external energy is supplied, the amount of basin water plays a crucial role in the solar still productivity. The basin water amount is recommended to be within $2 \mathrm{~cm}$ to $6 \mathrm{~cm}$ (Al-Hinai et al. 2002). However, for this study, 1.4, 1.6, 1.8 and $2.1 \mathrm{~cm}$ brine water depths are considered initially which equal around $3 \mathrm{~L}, 3.5 \mathrm{~L}, 4 \mathrm{~L}$ and $4.5 \mathrm{~L}$ basin water for the fabricated setup. In case the distillate production shows an increasing trend, further experiments are to be conducted.
For each water amount, experiments are performed for 3 days with the synthetic saline solution prepared in the laboratory with an approximate TDS of 5000 ppm. Based on the experimental results, an optimum water amount is to be fixed for further studies.

\section{Effect of salt concentration}

The concentration of salt in basin water also affects freshwater production from solar still. For this study, synthetic solutions are prepared with total dissolved solids of 2000, 5000 and 8000 ppm by adding sodium chloride. Experiments are carried out with optimized water amount found in Experiment 1 . The setup is operated for 3 days for each amount of salt concentration. Water parameter tests, e.g., $\mathrm{pH}$, total dissolved solids (TDS), electrical conductivity and chloride, are carried out both before and after the experiments to study the effectiveness in improving the water quality.

\section{Performance evaluation with seawater}

Seawater is collected and tested in the laboratory for selected parameters to assess the productivity of solar still with real seawater. Experiments are carried out with seawater for 3 days with the optimized basin water amount from Experiment 1. After the experiments, distillate samples are tested again for the selected parameters to compare removal efficiencies.

\section{Results and discussion}

\section{Effect of basin water depth}

The solar still productivity is evaluated with different basin water amount of $3.0 \mathrm{~L}, 3.5 \mathrm{~L}, 4.0 \mathrm{~L}$ and $4.5 \mathrm{~L}$ (Fig. 2).
Fig. 2 Variation of daily yield with different basin water amount

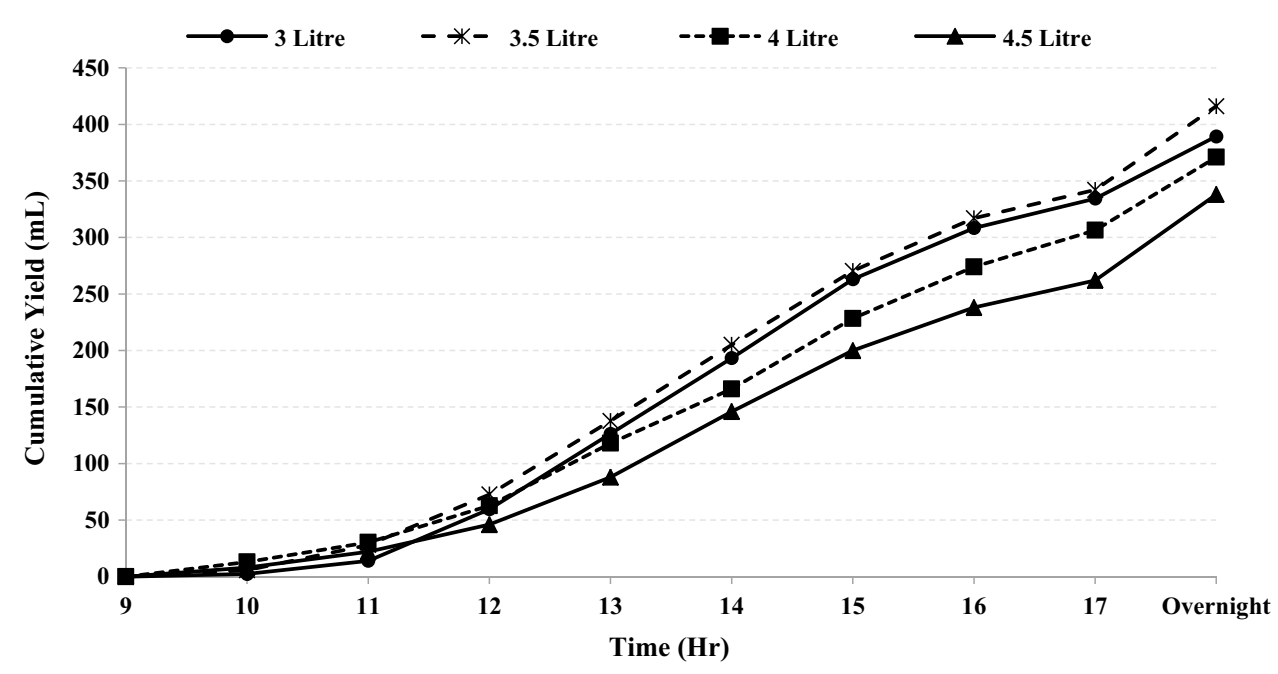


Highest water productions from solar still fed with $3 \mathrm{~L}, 3.5 \mathrm{~L}$, $4 \mathrm{~L}$ and $4.5 \mathrm{~L}$ are found to be $463 \mathrm{~mL}, 469 \mathrm{~mL}, 411 \mathrm{~mL}$ and $362 \mathrm{~mL}$, respectively, whereas average water productions are $389 \mathrm{~mL}, 416 \mathrm{~mL}, 371 \mathrm{~mL}$ and $338 \mathrm{~mL}$, respectively. With the increase in basin water amount from 3.5 to $4.0 \mathrm{~L}$, average water production from solar still reduces by $10.82 \%$. Average water production further reduces by $18.75 \%$ when basin water amount is increased from 3.5 to $4.5 \mathrm{~L}$. From this study, $3.5 \mathrm{~L}$, also analogous to $1.6 \mathrm{~cm}$ water depth, is selected as the optimum basin water since the highest average yield of $416 \mathrm{~mL}$ ( $1.94 \mathrm{~L} / \mathrm{m}^{2}$-day) is obtained from this configuration.

The experimental results from this study comply with findings reported by other researchers as shown in Table 1. According to the studies, freshwater production is inversely proportional to the basin water amount, i.e., lower basin water amount results in higher water production and vice versa (Khalifa and Hamood 2009). With the increase in basin water amount, the heat capacity of water increases that delays the evaporation process. As a result, freshwater production is also reduced. But too less basin water may develop dry spots in the basin that has a negative impact on the solar still productivity. The formation of dry spots may also cause outgassing of basin material which is not desirable (Kopperdal 2015).

Basin water temperature is directly related to the amount of water in the solar still basin that eventually affects solar still productivity (Fig. 3a-d). When basin water amount is increased, basin water temperature is lower in the early hours but is higher in the afternoon in case of greater water amount. Highest average basin water temperatures were recorded to be 64 ( 1 p.m.), 63 (1 p.m.), 60 (1 p.m.) and $61{ }^{\circ} \mathrm{C}$ (2 p.m.), while the highest hourly yield was recorded to be $70 \mathrm{~mL}$ (at 3 p.m.), $67 \mathrm{~mL}$ (at 2 p.m.), $62 \mathrm{~mL}$ (at 3 p.m.) and $58 \mathrm{~mL}$ ( 3 p.m.) for $3 \mathrm{~L}, 3.5 \mathrm{~L}, 4 \mathrm{~L}$ and $4.5 \mathrm{~L}$ basin water, respectively.
Water mass temperature decreases for the same solar radiation when the basin water amount is increased. As a result, shallow water depth gains temperature quickly from the incoming solar radiation due to its lower heat capacity, and evaporation is initiated quickly as compared to the solar still with higher basin water depth. This phenomenon also explains the decrease in solar still productivity with an increase in basin water depth. The 'time lag' between solar intensity and heat absorption by the basin water is pointed out by Dev et al. (2011) that explain the delay in the occurrence of the highest hourly yield at 2 p.m., while the highest basin water temperature is observed at 1 p.m.

\section{Effect of salt concentration}

The effect of salt concentration on the solar still productivity is studied with synthetic saline water consisting of the approximate TDS value of $2000 \mathrm{ppm}, 5000 \mathrm{ppm}$ and $8000 \mathrm{ppm}$ with the optimized basin water amount of $3.5 \mathrm{~L}$. From the experimental investigations, the average yield of solar still is found to be $508 \mathrm{~mL}, 488 \mathrm{~mL}$ and $471 \mathrm{~mL}$ for basin water TDS value of 2000, 5000 and 8000 ppm. With the increase in TDS from 2000 to 8000 ppm, water production drops by $7.28 \%$.

The experimental results are also supported by the literature. With the increase in salt concentration up to saturation point, water production decreases at a linear rate. Akash et al. (2000) reported the adverse effect of basin water salt concentration on solar still productivity. In an experimental study, Kalbasi and Esfahani (2010) increased basin water salinity from 0 to $3.5 \%$ and observed a $20 \%$ reduction in water production. When salinity increases in basin water, vapor pressure reduces at water surface that slows down evaporation process (Al-Shammiri 2002). As a result, freshwater production decreases with an increase in salinity.

Table 1 Study of basin water depth from the literatures

\begin{tabular}{|c|c|c|c|}
\hline Feature of the still & Basin water depth & Obtained results & References \\
\hline $\begin{array}{l}\text { Basin area: } 1 \mathrm{~m}^{2} \\
\text { Cover angle: } 23^{\circ}\end{array}$ & $10 \mathrm{~cm}$ to $0.5 \mathrm{~cm}$ & $19.6 \%$ increase in yield & Al-Hinai et al. (2002) \\
\hline $\begin{array}{l}\text { Basin area: } 1 \mathrm{~m}^{2} \\
\text { Cover angle: } 23^{\circ}\end{array}$ & $1,2,3 \mathrm{~cm}$ & Yield: $2.152,1.931$ and $0.826 \mathrm{~kg} / \mathrm{m}^{2}$-day & Dev et al. (2011) \\
\hline $\begin{array}{l}\text { Basin material: aluminum sheet }(3 \mathrm{~mm}) \\
\text { Basin area: } 1 \mathrm{~m}^{2} \\
\text { Cover angle: } 40^{\circ}\end{array}$ & $0.5,2,3,4 \mathrm{~cm}$ & Yield: $5.40,4.99,4.82,4.73 \mathrm{~L} / \mathrm{m}^{2}$-day & Tarawneh (2007) \\
\hline $\begin{array}{l}\text { Basin Material: Iron sheet }(1.4 \mathrm{~mm}) \\
\text { Basin area: } 1 \mathrm{~m}^{2} \\
\text { Cover angle: } 32^{\circ}\end{array}$ & $3.5 \mathrm{~cm}$ to $2 \mathrm{~cm}$ & $26 \%$ increase in yield & Badran (2007) \\
\hline $\begin{array}{l}\text { Basin area: } 1 \mathrm{~m}^{2} \\
\text { Cover angle: } 35^{\circ}\end{array}$ & $1,4,6,8,10 \mathrm{~cm}$ & $48 \%$ decrease in yield & Khalifa and Hamood (2009) \\
\hline $\begin{array}{l}\text { Basin material: Galvanized iron sheet }(2 \mathrm{~mm}) \\
\text { Basin area: } 1.19 \mathrm{~m}^{2} \\
\text { Cover angle: } 25^{\circ}\end{array}$ & $3 \mathrm{~cm}$ to $1 \mathrm{~cm}$ & $\begin{array}{l}\text { Thermal efficiency increased from } 15.3 \text { to } \\
57.1 \%\end{array}$ & Morad et al. (2015) \\
\hline
\end{tabular}


(a) Basin Water Amount: 3.0 Litre

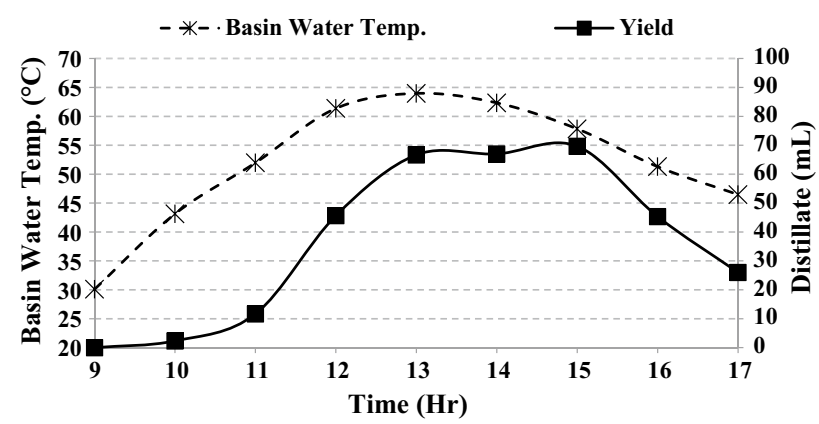

(b) Basin Water Amount: 3.5 Litre

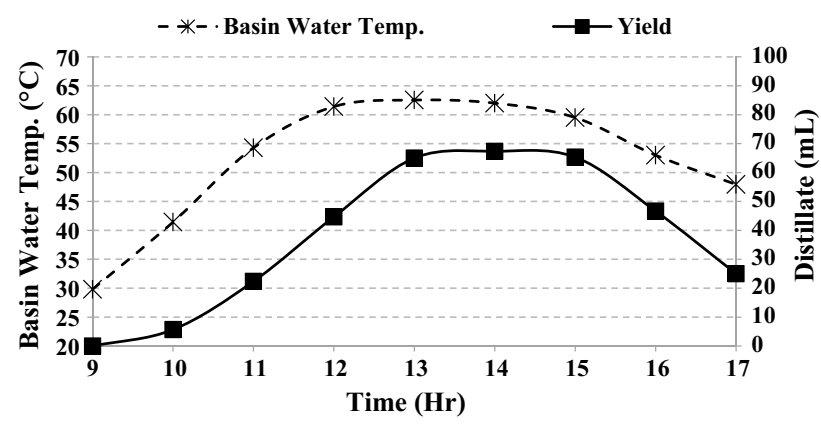

(c) Basin Water Amount: 4.0 Litre

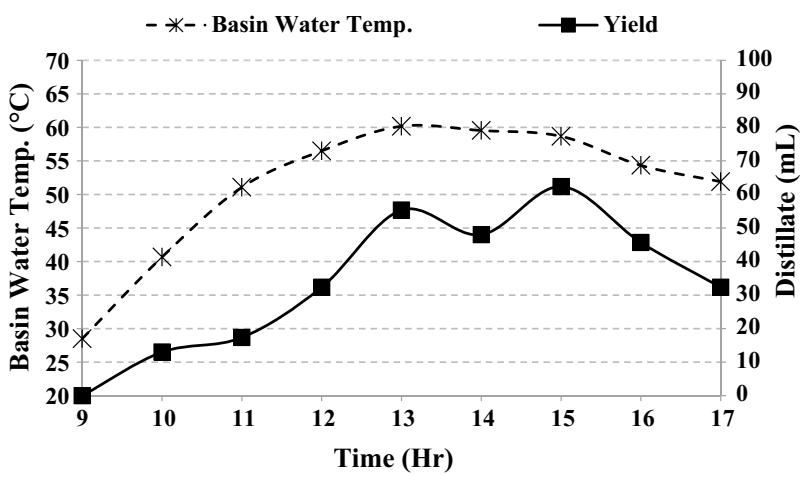

(d) Basin Water Amount: 4.5 Litre

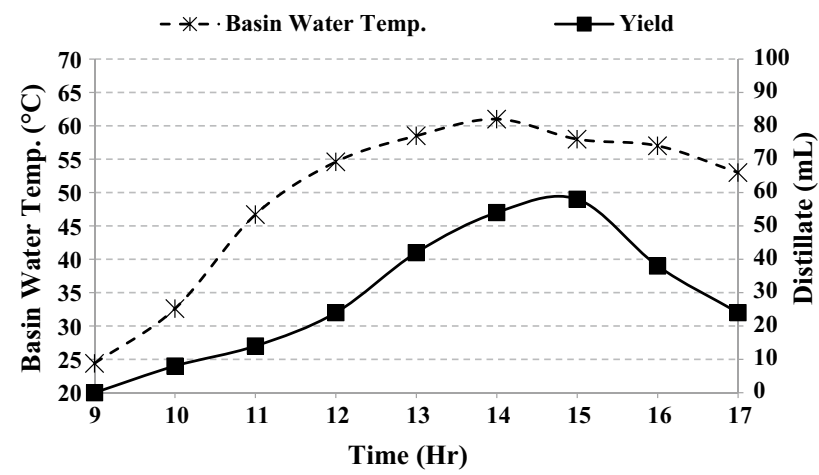

Fig. 3 Effect on basin water temperature and yield for basin water amount of a $3.0 \mathrm{~L} ; \mathbf{b} 3.5 \mathrm{~L} ; \mathbf{c} 4.0 \mathrm{~L} ; \mathbf{d} 4.5 \mathrm{~L}$
From Fig. 4a, basin water temperature decreases with an increase in basin water saline concentration. Gnanadason et al. (2015) opined that a fraction of solar radiation absorbed by basin water is spent in heating the dissolved salt in water which might be the reason for lower basin water temperature for higher salt concentration. Samuel et al. (2016) echoed similar behavior in their experiments. They identified salt as 'latent heat storage material' that has higher heat capacity. These explanations satisfy lower basin water temperature as well as lower freshwater production with an increase in salt concentration in basin water as shown in Fig. 4a, b.

\section{Performance evaluation with seawater}

Seawater is provided in the solar still with initial turbidity of $303 \mathrm{NTU}$, TDS value of 20,000 ppm and chloride concentration of $8309 \mathrm{ppm}$. Through experimental work, highest production is recorded to be $596 \mathrm{~mL}\left(2.79 \mathrm{~L} / \mathrm{m}^{2}\right.$-day), while average production is $509 \mathrm{~mL}\left(2.38 \mathrm{~L} / \mathrm{m}^{2}\right.$-day $)$. Samee et al. (2007) did similar experiments on raw water and found average water production to be $3.15 \mathrm{~L} / \mathrm{m}^{2}$-day.

Daily yield of seawater and synthetic water is compared in Fig. 5a. Recalling the experimental results of the effects of salt concentration, water production decreases with an increase in TDS. Since seawater has higher TDS (20,000 ppm) as compared to synthetic water (5000 ppm), synthetic water is supposed to produce a greater amount of distillate. But the opposite result is observed in this case. According to the findings of Paaijmans et al. (2008), suspended particles in water absorb and scatter sunlight. As a result, water temperature increases with an increase in water turbidity. Since synthetic water is prepared from tap water, turbidity is negligible for synthetic water. On the other hand, seawater has a turbidity of 303 NTU, which enables higher basin water temperature (Fig. 5b). Higher basin water temperature is associated with higher freshwater production from a solar still.

\section{Quality of produced water}

The main function of solar still is not to produce saline-free water only, but to produce water that confirms other drinking parameters as well. Solar still is supposed to eliminate a wide range of dissolved solids and also suspended solids responsible for turbidity. When basin water is heated by incoming solar radiation, water starts to evaporate from water surface leaving all the dissolves as well as suspended impurities behind. As a result, the distillate is expected to be of superior quality close to boiled water.

To assess the improvement in water quality after the experiments, both basin water samples and distillate samples have been tested. Five parameters are tested in this 
Fig. 4 Effect of basin water salt concentration on a Basin water temperature and $\mathbf{b}$ yield
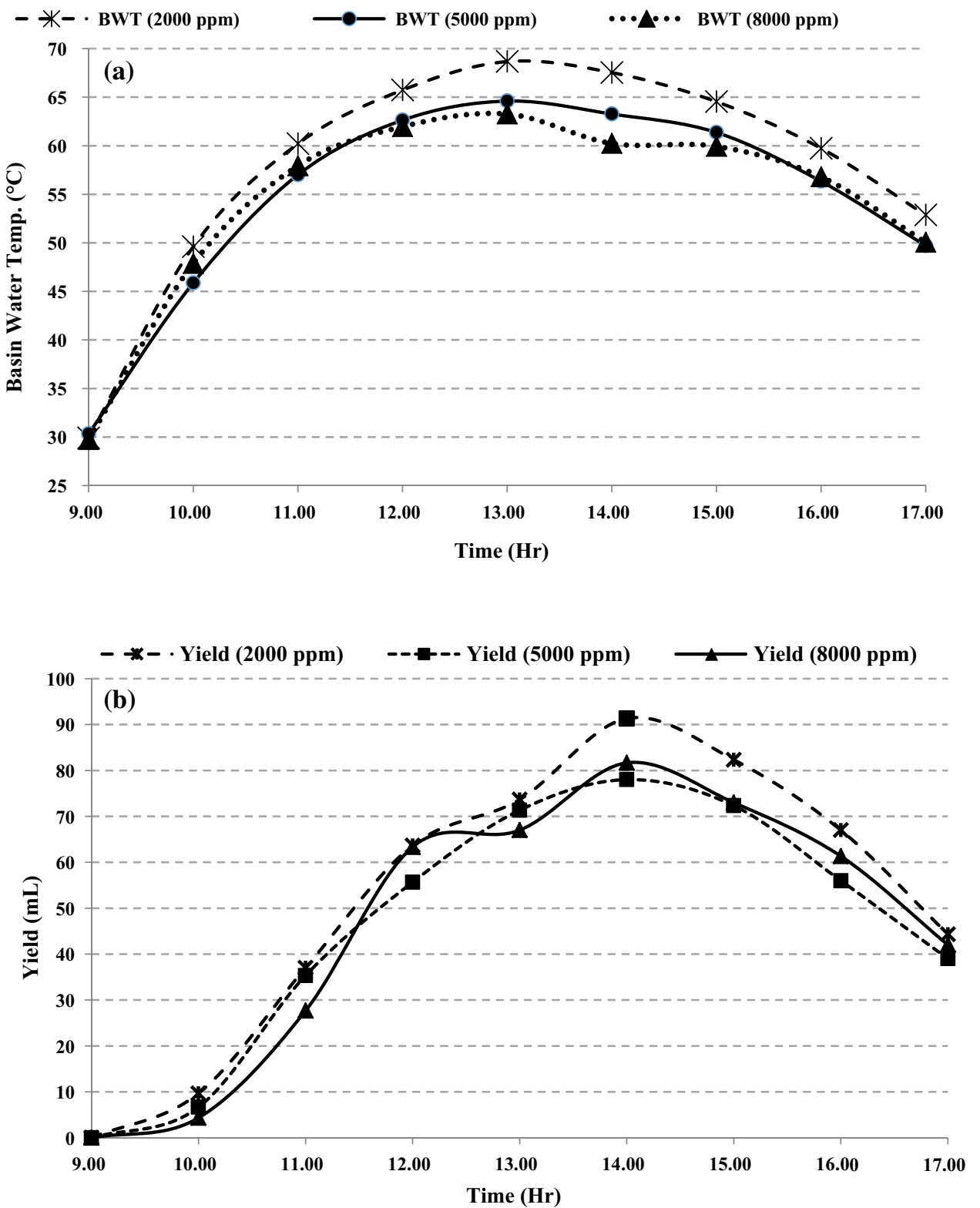

regard: $\mathrm{pH}$, turbidity, chloride, total dissolved solids and electrical conductivity.

Table 2 represents water parameter test results of both synthetic and saline water before and after the experiment.

After the desalination of water with the solar still, water parameters are improved significantly with more than $99 \%$ elimination of impurities as well as dissolved salt. All the parameters tested are within WHO guideline that ensures drinking quality of water produced from the solar still. The test results are in fair agreement with the experimental findings of other researchers. Dev et al. (2011) reported to produce distillate of similar property after the experiments $(\mathrm{EC}<100 \mu \mathrm{S} / \mathrm{cm}$ and TDS $<50 \mathrm{ppm})$, while Samee et al. (2007) also obtained distillate conforming WHO guideline.

\section{Conclusion}

The following outcomes of the study can be addressed:

- The productivity of a solar still is inversely proportional to the basin water amount; lower basin water yields higher freshwater and vice versa. With the increase in brine depth from $1.6 \mathrm{~cm}(3.5 \mathrm{~L})$ to $1.8 \mathrm{~cm}(4 \mathrm{~L})$, average freshwater production reduces by $10.82 \%$. Water production reduces by $18.75 \%$ when brine depth is increased from $1.6 \mathrm{~cm}(3.5 \mathrm{~L})$ to $2.1 \mathrm{~cm}(4.5 \mathrm{~L})$. Optimum basin water depth is found to be $1.6 \mathrm{~cm}$ for this study, which in terms of water amount is $16.34 \mathrm{~L} / \mathrm{m}^{2}$. 
Fig. 5 a Daily yield comparison of seawater and synthetic water; b Basin water temperature of seawater and synthetic water
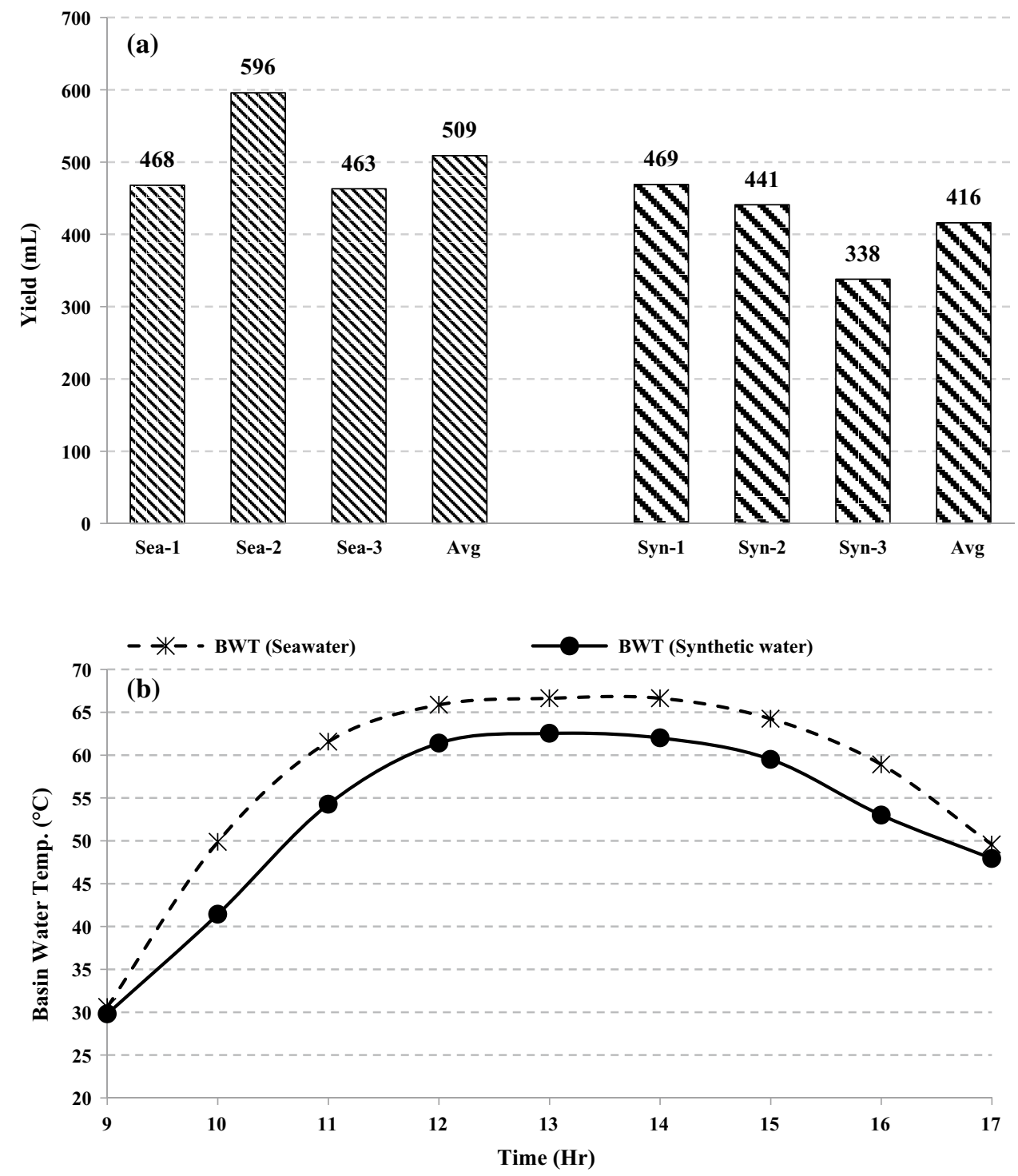

Table 2 Water parameter test results

\begin{tabular}{|c|c|c|c|c|c|c|c|c|}
\hline \multirow[t]{2}{*}{ Parameter } & \multirow[t]{2}{*}{ Unit } & \multicolumn{3}{|c|}{ Synthetic water } & \multicolumn{3}{|l|}{ Seawater } & \multirow[t]{2}{*}{ WHO guideline } \\
\hline & & Before & After & \%Removal & Before & After & $\%$ Removal & \\
\hline $\mathrm{pH}$ & - & 6.95 & 7.12 & - & 7.87 & 6.92 & - & $7-8$ \\
\hline Turbidity & NTU & $<5$ & $<5$ & - & 303 & 0.39 & 99.87 & 05 \\
\hline Chloride & ppm & 4505 & 10 & 99.78 & 8309 & 14 & 99.83 & 200 \\
\hline TDS & ppm & 9200 & 26 & 99.72 & 20,000 & 45 & 99.78 & 500 \\
\hline $\mathrm{EC}$ & $\mu \mathrm{S} / \mathrm{cm}$ & $13.1 \times 10^{3}$ & 32.2 & 99.75 & $28.5 \times 10^{3}$ & 55 & 99.81 & - \\
\hline
\end{tabular}

- Freshwater production decreases by $7.28 \%$ when basin water salt concentration is increased from 2000 to 8000 ppm.

- When supplied with seawater without any treatment, an average $2.38 \mathrm{~L} / \mathrm{m}^{2}$-day yield is obtained from the solar still.
- The quality of produced water is confirmed by test results ( $\mathrm{pH}$, turbidity, electrical conductivity, chloride and TDS) and the results are found to be within standard limits. Test results show $99.83 \%$ chloride removal and $99.78 \%$ TDS removal. 
Hence, it can be concluded that solar still can be a good and effective solution for producing fresh water from saline water in coastal areas of low-income countries, where modern desalination techniques are not suitable due to high initial investment and higher maintenance cost.

Acknowledgements The authors wish to express their gratitude toward the Environmental Engineering Laboratory, Department of Civil Engineering, Chittagong University of Engineering and Technology (Thesis grant) for all the cooperations for the fulfillment of this study.

Open Access This article is distributed under the terms of the Creative Commons Attribution 4.0 International License (http://creativeco mmons.org/licenses/by/4.0/), which permits unrestricted use, distribution, and reproduction in any medium, provided you give appropriate credit to the original author(s) and the source, provide a link to the Creative Commons license, and indicate if changes were made.

\section{References}

Abujazar MSS, Fatihah S, Rakmi AR, Shahrom MZ (2016) The effects of design parameters on productivity performance of a solar still for seawater desalination: a review. Desalination 385:178-193

Akash BA, Mohsen MS, Nayfeh W (2000) Experimental study of the basin type solar still under local climate conditions. Energy Convers Manag 41(9):883-890

Al-Hinai H, Al-Nassri M, Jubran B (2002) Effect of climatic, design and operational parameters on the yield of a simple solar still. Energy Convers Manag 43(13):1639-1650

Al-Shammiri M (2002) Evaporation rate as a function of water salinity. Desalination 150(2):189-203

Ayoub GM, Malaeb L (2012) Developments in solar still desalination systems: a critical review. Crit Rev Environ Sci Technol 42(19):2078-2112

Badran OO (2007) Experimental study of the enhancement parameters on a single slope solar still productivity. Desalination 209(1-3):136-143

Buros OK (2000) The ABC's of desalting. International Desalination Association. https://www.water.ca.gov/LegacyFiles/pubs/surfa cewater/abcs_of_desalting/abcs_of_desalting.pdf. Accessed 24 July 2018

Dev R, Abdul-Wahab SA, Tiwari GN (2011) Performance study of the inverted absorber solar still with water depth and total dissolved solid. Appl Energy 88(1):252-264

Gnanadason MK, Kumar PS, Wilson VH, Kumaravel A (2015) Productivity enhancement of a-single basin solar still. Desalin Water Treat 55(8):1998-2008
Hoque MR (2009) Access to safe drinking water in rural Bangladesh: water governance by DPHE. Dissertation, Institute of Governance Studies, BRAC University, Dhaka, Bangladesh

https://reliefweb.int/sites/reliefweb.int/files/resources/261424e.pdf. Accessed 30 Jan 2019

Kalbasi R, Esfahani MN (2010) Multi-effect passive desalination system, an experimental approach. World Appl Sci J 10(10):1264-1271

Khalifa AJN, Hamood AM (2009) On the verification of the effect of water depth on the performance of basin type solar stills. Sol Energy 83(8):1312-1321

Kopperdal HH (2015) Design, prototyping and field testing of solar stills in remote areas in Afghanistan. Dissertation, Norwegian University of Life Sciences, Norway

Morad MM, El-Maghawry HAM, Wasfy KI (2015) Improving the double slope solar still performance by using flat-plate solar collector and cooling glass cover. Desalination 373:1-9

Paaijmans KP, Takken W, Githeko AK, Jacobs AFG (2008) The effect of water turbidity on the near-surface water temperature of larval habitats of the malaria mosquito Anopheles gambiae. Int J Biometeorol 52(8):747-753

Samee MA, Mirza UK, Majeed T, Ahmad N (2007) Design and performance of a simple single basin solar still. Renew Sustain Energy Rev 11(3):543-549

Samuel DGH, Nagarajan PK, Sathyamurthy R, El-Agouz SA, Kannan $E$ (2016) Improving the yield of fresh water in conventional solar still using low cost energy storage material. Energy Convers Manag 112:125-134

Singh HN, Tiwari GN (2004) Monthly performance of passive and active solar stills for different Indian climatic conditions. Desalination 168:145-150

Srivastava PK, Agrawal SK (2013) Experimental and theoretical analysis of single sloped basin type solar still consisting of multiple low thermal inertia floating porous absorbers. Desalination 311:198-205

Tarawneh MSK (2007) Effect of water depth on the performance evaluation of solar still. Jordan J Mech Indust Eng 1(1):23-29

Tiwari GN, Singh HN, Tripathi R (2003) Present status of solar desalination. Sol Energy 75(5):367-373

WWAP (United Nations World Water Assessment Programme)/UNWater (2018) The United nations world water development report 2018: nature-based solutions for water. UNESCO, Paris

Publisher's Note Springer Nature remains neutral with regard to jurisdictional claims in published maps and institutional affiliations. 